\title{
Catalytic Metal-free Deoxygenation of Nitrous Oxide with Disilanes
}

\author{
Lucile Anthore-Dalion*, Emmanuel Nicolas, and Thibault Cantat* \\ NIMBE (UMR 3685), CEA, CNRS, Université Paris-Saclay, CEA Paris-Saclay, 91191 Gif-sur-Yvette Cedex (France).
}

\author{
Supporting Information Placeholder
}

\begin{abstract}
Due to its high kinetic stability, conditions to reduce the greenhouse gas $\mathrm{N}_{2} \mathrm{O}$ are limited, hence requiring a better understanding of its chemistry and of the $\mathrm{N}-\mathrm{O}$ bond cleavage. In this work, $\mathrm{N}_{2} \mathrm{O}$ was deoxygenated under metal-free conditions. Using disilanes as reducing agents and a catalytic amount of fluoride anions or alkoxides allowed a mild reduction at ambient pressure and temperature. DFT calculations unveiled the mechanism, which shows a nucleophilic addition of a silyl anion to the central $\mathrm{N}$ atom of $\mathrm{N}_{2} \mathrm{O}$ and release of $\mathrm{N}_{2}$ from a pseudo-Brook rearrangement. KEYWORDS: nitrous oxide, organocatalysis, reduction, fluoride, disilanes
\end{abstract}

In the natural nitrogen cycle, nitrous oxide, also called "laughing gas", is the last intermediate of the denitrification process, which transforms nitrates into atmospheric dinitrogen. ${ }^{1}$ Because of human activities, such as agriculture, waste management, and industrial productions of adipic and nitric acid, its atmospheric concentration has significantly increased in the last centuries (20\% since 1750$),{ }^{2}$ raising environmental issues. $\mathrm{N}_{2} \mathrm{O}$ is indeed the most potent ozonedepleting substance and a greenhouse gas, ${ }^{3}$ estimated to be 298 times more potent than $\mathrm{CO}_{2} .{ }^{4}$ This has led to a growing interest in its chemical reactivity and to the development of end-of-the-pipe technologies to reduce industrial emissions. ${ }^{5}$

From a synthetic point of view, nitrous oxide is kinetically highly stable $^{6}$ and a poor ligand for transition metals. ${ }^{7}$ Hence, reactions with this gas often require harsh conditions in presence of heterogeneous catalysts (typically $>200{ }^{\circ} \mathrm{C}$ and $>25$ bar for alkenes oxidation). ${ }^{8}$ Only few examples of reactions with $\mathrm{N}_{2} \mathrm{O}$ occur under homogeneous and milder reaction conditions. ${ }^{9}$ In most cases, $\mathrm{N}_{2} \mathrm{O}$ has been used as an oxidant $\left(\mathrm{E}^{\circ}\left(\mathrm{N}_{2} \mathrm{O} / \mathrm{N}_{2}\right)=1.77 \mathrm{~V} \text { vs SHE}\right)^{10}$ and usually reacts with highly reactive organometallic species via oxygen atom transfer. ${ }^{11}$ This reactivity has enabled the development of transition metal-catalyzed transformations where $\mathrm{N}_{2} \mathrm{O}$ is deoxygenated in the presence of reductants such as Grignard reagents, ${ }^{12}$ phosphines, ${ }^{13}$ aldehydes,${ }^{14}$ alcohols ${ }^{15}$ or CO.${ }^{16}$ Recently, Milstein and coworkers showed that the reduction of nitrous oxide can even be performed using $\mathrm{H}_{2}$, with a PNP pincer ruthenium complex as catalyst (Scheme 1) ${ }^{17}$ So far, there is however no example of metalfree deoxygenation of $\mathrm{N}_{2} \mathrm{O}$ under mild conditions.

To better apprehend the reactivity of the $\mathrm{N}-\mathrm{O}$ bond and overcome the kinetic stability of $\mathrm{N}_{2} \mathrm{O}$, we chose to use disilane derivatives as reducing agents. They are indeed efficient and mild deoxygenating agents due to the high oxophilicity of silicon, and easier to activate than hydrogen thanks to a lower bond dissociation energy (79.7 kcal.mol ${ }^{-1}$ in $\mathrm{Me}_{3} \mathrm{SiSiMe}_{3}$ vs $104 \mathrm{kcal}^{\mathrm{mol}}{ }^{-1}$ in $\left.\mathrm{H}_{2}\right) .{ }^{18}$ Moreover, $\mathrm{N}_{2} \mathrm{O}$ is known to react with tetramethylsilane in absence of catalysts but only under harsh conditions (>2 000 bar, $\left.>360{ }^{\circ} \mathrm{C}\right) ;{ }^{19}$ a transformation used for the passivation of electronical devices by chemical vapor deposition ("Semi Insulating Polycrystalline Silicon" (SIPOS)). ${ }^{20}$ Milstein et al. have also used their ruthenium catalyst to perform $\mathrm{N}_{2} \mathrm{O}$ reduction with hydrosilanes under milder reaction conditions (3.4 bar, $65^{\circ} \mathrm{C}$, Scheme 1). ${ }^{17}$

We show herein that the deoxygenation of $\mathrm{N}_{2} \mathrm{O}$ can even be carried out under ambient conditions $\left(1 \mathrm{bar}, 20^{\circ} \mathrm{C}\right)$ without any transition metal by using disilanes in the presence of a catalytic amount of fluoride anions or alkoxides (Scheme 1). Mechanistic investigations unveiled the mechanism at play in the $\mathrm{N}-\mathrm{O}$ bond cleavage.

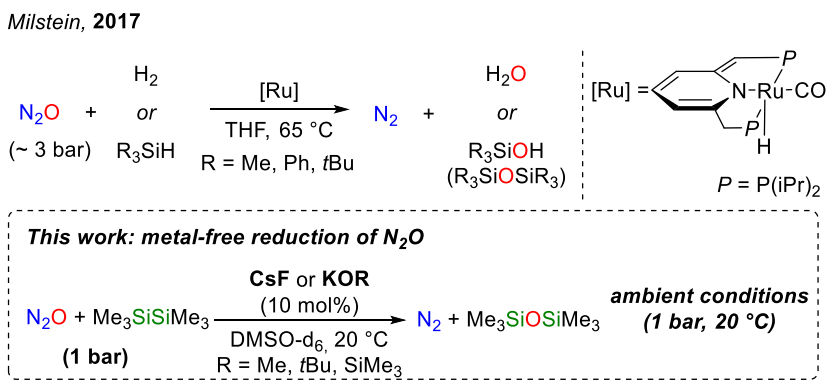

Scheme 1. Catalytic reduction of nitrous oxide with $\mathrm{H}_{2}$ or organosilanes.

To start our investigations, we selected hexamethyldisilane (1) as a readily available and moisture stable reductant. Fluoride anions were screened as catalysts since they are known to efficiently activate disilanes. ${ }^{21,22}$ Exposing a DMSO solution of disilane $\mathbf{1}$ to an atmosphere of $\mathrm{N}_{2} \mathrm{O}$ ( 1 bar), in the presence of a catalytic amount of $\mathrm{CsF}(10 \mathrm{~mol} \%)$, resulted in the formation of $77 \%$ hexamethyldisiloxane (2) within $4 \mathrm{~h}$ at $20^{\circ} \mathrm{C}$. Analysis of the gas phase by gas chromatography (GC) indicated the quantitative conversion of $\mathrm{N}_{2} \mathrm{O}$ into $\mathrm{N}_{2}\left(\mathrm{~N}_{2} / \mathrm{N}_{2} \mathrm{O} 99: 1\right)$ (Table 1 , entry 1$)$. No reaction took place without catalyst, even after 3 days (Table 1 , entry 2). ${ }^{23}$ Strictly anhydrous conditions were necessary to avoid the competitive deoxygenation of $\mathrm{H}_{2} \mathrm{O}$ leading to $\mathrm{H}_{2}$ production (Figure S8). Remarkably, the reaction could be scaled-up to $1.78 \mathrm{mmol}$ of disilane 1 without any modification of the protocol, and furnished disiloxane 2 in $75 \%$ yield. Other alkali metal fluoride salts $(\mathrm{LiF}, \mathrm{NaF}, \mathrm{KF})$ did not catalyze the reaction, certainly due to their lower solubilities (Table 1, entries 3-5). In contrast, with tetramethyl ammonium fluoride (TMAF), an anhydrous and solid surrogate of tetrabutyl ammonium fluoride, an increased activity was noted (Table 1 , entry $6)$. The reaction proved to be however much slower with the moisture stable $\mathrm{KHF}_{2}$ and tetrabutylammonium difluorotriphenyl-silicate (TBAT) as catalysts (Table 1, entries 7 and 8). In these latter cases, the fluoride anion is indeed not naked, and hence less reactive. 
Disilanes can also be activated by non-fluorinated bases such as alkoxides. ${ }^{24}$ In fact, both $\mathrm{KOMe}$ and $\mathrm{KO} t \mathrm{Bu}$ catalyzed the reaction, leading to full conversion of $\mathrm{N}_{2} \mathrm{O}$ within $1 \mathrm{~h}$ and $2 \mathrm{~h}$, respectively (Table 1, entries 9 and 10). At this stage, KOMe and $\mathrm{KO} t \mathrm{Bu}$ could act as precatalysts for the generation of a silanolate species. ${ }^{21 a, c}$ This hypothesis was validated by the successful use of $\mathrm{KOSiMe}_{3}$ as a catalyst (Table 1, entry 11).

Interestingly, no reaction was detected in either THF or MeCN, even when 18-crown-6 was added to help solubilize CsF. In contrast, when a DMSO/THF 1:1 mixture was used as solvent, the reaction proceeded but required $48 \mathrm{~h}$ to reach full conversion, showing a detrimental effect of THF (Table S2). This observation was ascribed to a lower solubility of both the fluorinated base and $\mathrm{N}_{2} \mathrm{O}$ in less polar solvents.

Table 1. Catalyst screening for the reduction of $\mathrm{N}_{2} \mathrm{O}$ with disilane 1. ${ }^{\text {[a] }}$

\begin{tabular}{|c|c|c|c|c|c|}
\hline & $\begin{array}{c}\mathrm{N}_{2} \mathrm{O}+\mathrm{Me}_{3} \mathrm{SiSiMe} \\
\mathbf{1}\end{array}$ & $\frac{\text { cat }}{\mathrm{DMSC}}$ & $\frac{0 \mathrm{~mol} \%)}{\mathrm{d}_{6,2}, 2{ }^{\circ} \mathrm{C}}$ & \multicolumn{2}{|c|}{$\begin{array}{c}{ }_{2}+\mathrm{Me}_{3} \mathrm{SiOSiMe}_{3} \\
\mathbf{2}\end{array}$} \\
\hline Entry & Cat. & Time & $\begin{array}{c}\text { Conversion } \\
\text { of } 1(\%)^{[b]}\end{array}$ & $\begin{array}{l}\text { Yield in } \\
\mathbf{2}(\%)^{[\mathrm{b}]}\end{array}$ & $\underset{[\mathrm{c}]}{\mathrm{N}_{2} / \mathrm{N}_{2} \mathrm{O}}$ \\
\hline 1 & $\mathrm{CsF}$ & $4 \mathrm{~h}$ & 92 & 77 & $99: 1$ \\
\hline 2 & - & 3 days & 0 & 0 & $5: 95$ \\
\hline 3 & $\mathrm{LiF}$ & $24 \mathrm{~h}$ & 12 & 0 & $10: 90$ \\
\hline 4 & $\mathrm{NaF}$ & $24 \mathrm{~h}$ & 8 & 0 & $5: 95$ \\
\hline 5 & $\mathrm{KF}$ & $24 \mathrm{~h}$ & 2 & 0 & $7: 93$ \\
\hline 6 & TMAF & $1 \mathrm{~h}$ & 100 & 76 & $97: 3$ \\
\hline 7 & $\mathrm{KHF}_{2}$ & $24 \mathrm{~h}$ & 35 & 2 & $25: 75^{[\mathrm{e}]}$ \\
\hline $8^{[\mathrm{d}]}$ & TBAT & $24 \mathrm{~h}$ & 28 & 11 & $30: 70$ \\
\hline 9 & KOMe & $1 \mathrm{~h}$ & 98 & 85 & $100: 0^{[\mathrm{e}]}$ \\
\hline 10 & $\mathrm{KO} t \mathrm{Bu}$ & $2 \mathrm{~h}$ & 92 & 62 & $100: 0^{[\mathrm{e}]}$ \\
\hline 11 & $\mathrm{KOSiMe}_{3}$ & $4 \mathrm{~h}$ & 86 & 80 & $90: 10^{[\mathrm{e}]}$ \\
\hline
\end{tabular}

[a] Conditions: $\mathrm{N}_{2} \mathrm{O}(1 \mathrm{bar}, \approx 2 \mathrm{~mL}),\left(\mathrm{Me}_{3} \mathrm{Si}\right)_{2}(0.12 \mathrm{mmol})$, catalyst $(12 \mu \mathrm{mol}, 10 \mathrm{~mol} \%)$, DMSO-d $6(0.5 \mathrm{~mL})$. [b] Conversions and yields measured by GC-MS analysis. Internal standard: 1,3,5-trimethoxybenzene. The difference between conversion and yield is ascribed to the volatility of the silylated compounds and to the production of $\mathrm{Me}_{3} \mathrm{SiF}$, $\mathrm{Me}_{3} \mathrm{SiOMe}$ or $\mathrm{Me}_{3} \mathrm{SiOtBu}$ in the course of the reaction. [c] Corrected GC-ratios. Residual amount of $\mathrm{N}_{2}$ from the atmosphere $<10 \%$ [d] Scrambling of $\mathrm{R}_{3} \mathrm{Si}$ residues: $\mathrm{Ph}_{3} \mathrm{SiF}$ and $\mathrm{Ph}_{3} \mathrm{SiOSiMe}_{3}$ are detectable in GCMS. [e] $\mathrm{H}_{2}$ is also detected in $\mathrm{GC}(<2 \%)$. See SI for more details (p. S7).

To test the influence of the stereoelectronic properties of the silane reductant, the deoxygenation of $\mathrm{N}_{2} \mathrm{O}$ was carried out with $\left(\mathrm{PhMe}_{2} \mathrm{Si}\right)_{2}(3)$ and $\left(\mathrm{Ph}_{2} \mathrm{MeSi}\right)_{2}(4)$ (Table 2, entries 2 and 3). Interestingly, the more Lewis acidic the disilane was, the faster the reaction proceeded, as reflected in the yields in the corresponding siloxanes, after $1 \mathrm{~h}$, of $55 \%, 63 \%$ and $68 \%$, for disilanes $\mathbf{1 , 3}$ and $\mathbf{4}$, respectively (Table 2). In contrast, neither (Bpin) $)_{2}$ nor $\mathrm{PhMe}_{2} \mathrm{Si}$ Bpin proved successful under these conditions.

Unfortunately, no intermediate could be either isolated or observed by NMR in the course of the reaction or through stoichiometric reactions. Hence DFT calculations were used (for computational details see SI, part V), to track how the $\mathrm{N}-\mathrm{O}$ bond is cleaved under mild and metal-free conditions to promote the reduction of the kinetically stable $\mathrm{N}_{2} \mathrm{O}$ molecule. According to the experimental results, $\mathrm{CsF}$ and $\mathrm{KOSiMe}_{3}$ show a similar activity (Table 1, entries 1 and 11), and the latter was hence selected as a catalyst in the mechanism depicted in Scheme 2. The role of the fluoride anion (or alkoxides) as a precatalyst (mechanism A) or as a catalyst (mechanism B) is also explored, thereafter.
Table 2. Screening of disilanes for the reduction of $\mathrm{N}_{2} \mathrm{O}^{\text {[a] }}$

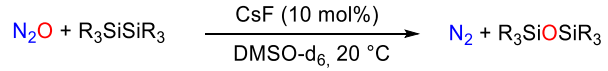

\begin{tabular}{ccccc}
\hline Entry & $\mathrm{R}_{3} \mathrm{SiSiR}_{3}$ & $\begin{array}{c}\text { Yield }^{[\mathrm{b}]} \\
\text { after } 1 \mathrm{~h}\end{array}$ & Final yield ${ }^{[\mathrm{b}]}$ & $\mathrm{N}_{2} / \mathrm{N}_{2} \mathrm{O}^{[\mathrm{c}]}$ \\
\hline 1 & $\left(\mathrm{Me}_{3} \mathrm{Si}\right)_{2}(\mathbf{1})$ & $55 \%$ & $77 \%(4 \mathrm{~h})$ & $99: 1$ \\
2 & $\left(\mathrm{PhMe}_{2} \mathrm{Si}\right)_{2}(\mathbf{3})$ & $63 \%$ & $93 \%(3 \mathrm{~h})$ & $100: 0$ \\
$3^{[\mathrm{d}]}$ & $\left(\mathrm{Ph}_{2} \mathrm{MeSi}\right)_{2}(\mathbf{4})$ & $68 \%$ & $93 \%(2 \mathrm{~h})$ & $100: 0$
\end{tabular}

[a] Conditions: $\mathrm{N}_{2} \mathrm{O}(1 \mathrm{bar}$, ca. $2 \mathrm{~mL}), \mathrm{R}_{3} \mathrm{SiSiR}_{3}(0.12 \mathrm{mmol})$, catalyst $(12 \mu \mathrm{mol}, 10 \mathrm{~mol} \%)$, DMSO-d $\mathrm{d}_{6}(0.5 \mathrm{~mL})$. [b] Yields measured by GCanalysis (disilane 1) or by NMR-analysis (compounds $\mathbf{3}$ and 4). Internal standard: 1,3,5-trimethoxybenzene. [c] Corrected GC-ratios. Residual amount of $\mathrm{N}_{2}$ from the atmosphere $<10 \%$. [d] To overcome the poor solubility of the starting material in DMSO, the reaction mixture was stirred $2 \mathrm{~h}$ at $20{ }^{\circ} \mathrm{C}$ under argon prior to adding $\mathrm{N}_{2} \mathrm{O}$. See SI for more details (p. S11).

The silanolate $\mathrm{Me}_{3} \mathrm{SiO}^{-}$(I) can react either with $\mathrm{N}_{2} \mathrm{O}$ or with $\left(\mathrm{Me}_{3} \mathrm{Si}\right)_{2}(\mathbf{1})$. Whereas the activation barrier of the reaction with $\mathrm{N}_{2} \mathrm{O}$ was high in energy $\left(\Delta G^{*}=+44.4 \mathrm{kcal} \mathrm{mol}^{-1}\right.$, Figure S10), the nucleophilic addition of silanolate $\mathbf{I}$ to disilane $\mathbf{1}$ appeared more favorable $\left(\Delta \mathrm{G}^{\dagger}=+18.5 \mathrm{kcal}^{\mathrm{mol}} \mathrm{mo}^{-1}\right)$. After release of the siloxane $\left(\mathrm{Me}_{3} \mathrm{Si}\right)_{2} \mathrm{O}(2)$, it generates a highly nucleophilic $\mathrm{Me}_{3} \mathrm{Si}^{-}$anion (III), in an overall exergonic sequence $\left(\Delta \mathrm{G}=-4.7 \mathrm{kcal}^{\mathrm{mol}} \mathrm{m}^{-1}\right)$ (Figure 1c). This result is supported by the observation in NMR of the instantaneous formation of $\mathrm{Me}_{3} \mathrm{SiOSiMe}_{3}$ (2) when $\mathrm{KOSiMe}_{3}$ and disilane $\mathbf{1}$ are mixed (Figure S7).

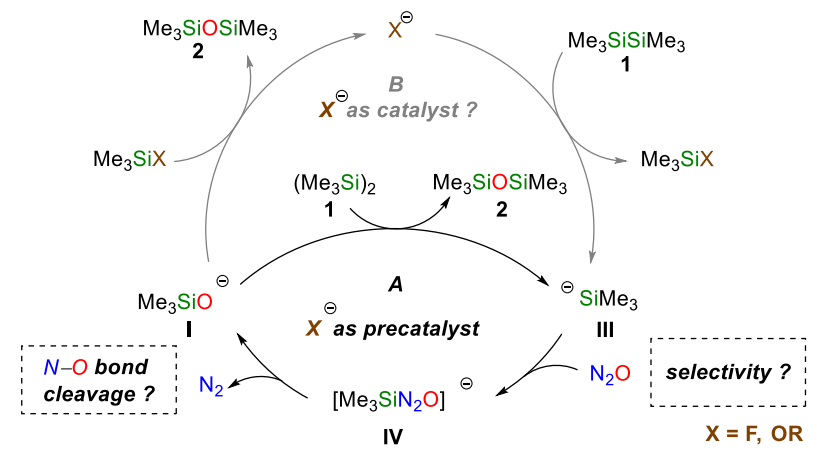

Scheme 2. Two plausible mechanisms: with the fluoride anion or the alkoxides as precatalysts (A) or as catalysts (B).

In contrast to silanolate I, silyl anion III efficiently reacts with $\mathrm{N}_{2} \mathrm{O}$ via a nucleophilic attack. Considering that the two degenerate LUMOs of $\mathrm{N}_{2} \mathrm{O}$ are mostly developed on the two nitrogen atoms (Figure 1a), the nucleophilic attack can occur either on the central or the terminal nitrogen centers. Computational results show a significant difference in the activation barrier energy of both pathways: the nucleophilic attack of $\mathrm{Me}_{3} \mathrm{Si}^{-}$(III) on the central nitrogen is kinetically favored by $10.8 \mathrm{kcal} . \mathrm{mol}^{-1}$ (TS $\mathbf{T}_{\mathbf{3}}$ and $\mathbf{T S} \mathbf{S}_{\mathbf{3}}$ ) and, under the applied conditions $\left(20^{\circ} \mathrm{C}\right)$, the attack on the terminal $\mathrm{N}$ atom is hardly accessible $\left(\Delta \mathrm{G}^{\ddagger}=+26.2 \mathrm{kcal} . \mathrm{mol}^{-1}\right)$. As such, the less stable $\mathrm{Me}_{3} \mathrm{Si}\left(\mathrm{N}_{2} \mathrm{O}\right)^{-}$intermediate $\mathrm{IV}$ is the major product. Little is known about the ambivalent reactivity of $\mathrm{N}_{2} \mathrm{O}$ as an electrophile. According to DFT calculations, metal-hydride complexes attack preferentially at the terminal nitrogen. ${ }^{25}$ Likewise, non-metallic systems, such as $N$-heterocyclic carbenes reported by Severin et al. ${ }^{26}$ or frustrated Lewis pairs, ${ }^{27}$ have been experimentally shown to react via the terminal nitrogen of $\mathrm{N}_{2} \mathrm{O}$. The selectivity observed in our system is reversed and follows the principle of least nuclear motion, ${ }^{28}$ with an addition of the silyl anion to the nitrogen atom bearing the highest positive charge and a corresponding transition state ( $\mathbf{T S}_{3}$ ) that minimizes the bond elongations in the $\mathrm{N}_{2} \mathrm{O}$ fragment (Figure 1a and SI). 


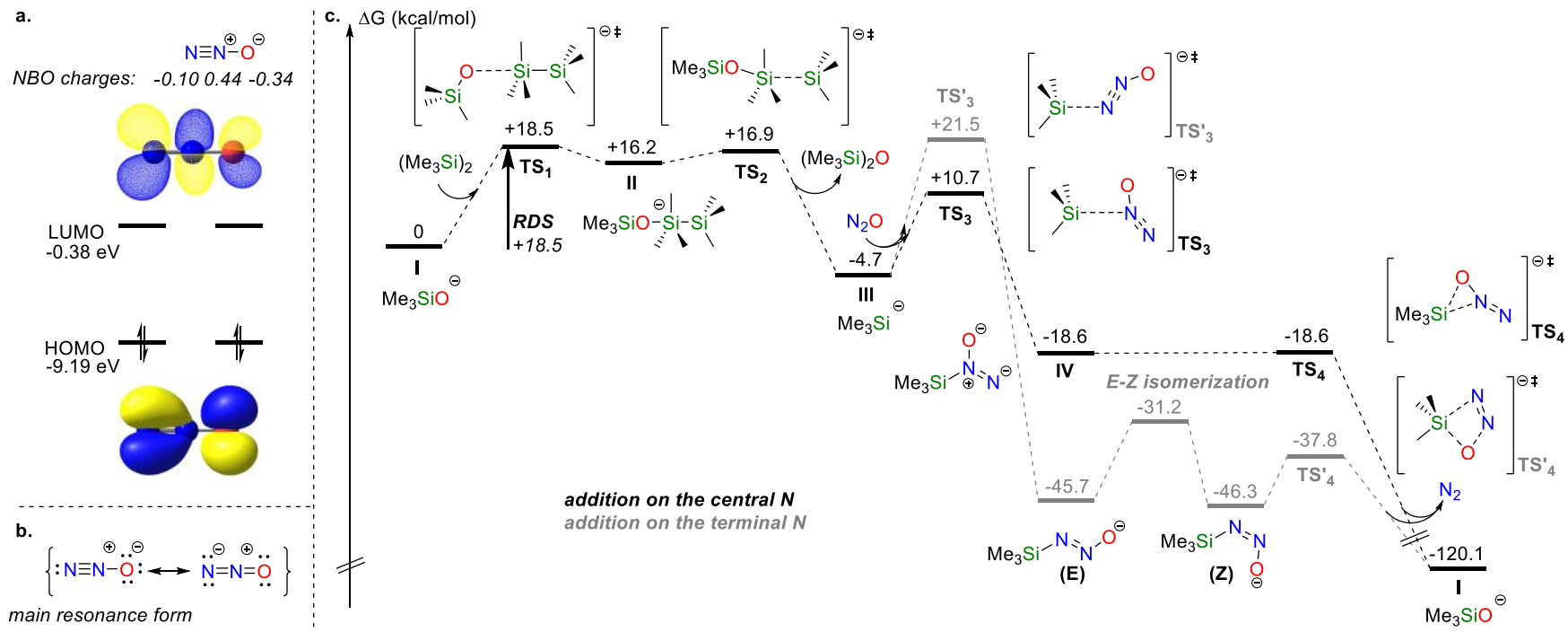

Figure 1. $\mathrm{N}_{2} \mathrm{O}$ structure and computed mechanism. [a] $\mathrm{NBO}$ charges and frontier molecular orbitals of $\mathrm{N}_{2} \mathrm{O}$ [b] Main resonance structures of $\mathrm{N}_{2} \mathrm{O}$ [c] Reaction mechanism starting from silanolate I. Gibbs free energies in kcal.mol ${ }^{-1}$ computed at the B3LYP-D3/6-31G* $(\mathrm{C}, \mathrm{H}, \mathrm{F}, \mathrm{N}, \mathrm{O})$ and B3LYP-D3/6-311+G** (Si) level of theory, using PCM=DMSO to account for solvation

From the $\mathrm{Me} 3 \mathrm{Si}\left(\mathrm{N}_{2} \mathrm{O}\right)^{-}$intermediate $(\mathbf{I V})$, an essentially barrierless and highly exergonic [1,2]-pseudo-Brook rearrangement occurs through the 3-center transition state $\mathbf{T S}_{\mathbf{4}}\left(\Delta \mathrm{G}=-102 \mathrm{kcal}^{\mathrm{m}} \mathrm{mol}{ }^{-}\right.$ ${ }^{1}$ ), in which the cleavage of the $\mathrm{N}-\mathrm{O}$ bond is compensated by the synchronized formation of the stable $\mathrm{Si}-\mathrm{O}$ bond, to release $\mathrm{N}_{2}$. Such an intramolecular rearrangement has also been proposed for $\mathrm{CO}_{2}$ reduction with disilanes by Skrydstrup et al. ${ }^{21 \mathrm{a}, \mathrm{c}}$ and in the reaction of KHMDS with $\mathrm{N}_{2} \mathrm{O}$ to synthesize potassium azide, where a $[1,4]$-silicon shift has been suggested. ${ }^{29}$ The overall reaction between $\mathrm{N}_{2} \mathrm{O}$ and hexamethyldisilane (1) is thus highly exergonic by $120.1 \mathrm{kcal} . \mathrm{mol}^{-1}$, and the first nucleophilic substitution at the silicon atom is the rate determining step (RDS), with an energetic barrier of $18.5 \mathrm{kcal}^{\mathrm{mol}}{ }^{-1}$ (TS 1 , Figure 1c).

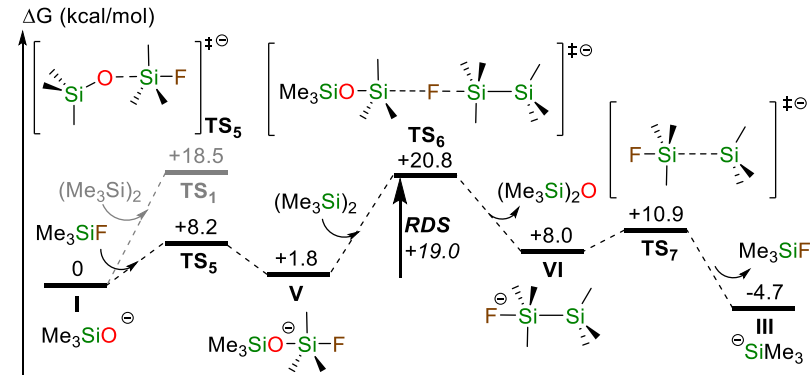

Figure 2. Possible pathway for the regeneration of silyl anion $\mathrm{Me}_{3} \mathrm{Si}^{-}$(III) in presence of a catalytic amount of fluoride anions. Gibbs free energies in kcal.mol-1 computed at the B3LYP-D3/6$31 \mathrm{G}^{*}(\mathrm{C}, \mathrm{H}, \mathrm{F})$ and B3LYP-D3/6-311+G** $(\mathrm{Si})$ level of theory, using $\mathrm{PCM}=\mathrm{DMSO}$ to account for solvation.

With this mechanism in hands, we then investigated the role of the catalytic species, using the fluoride system as a model. Addition of $\mathrm{F}^{-}$to the hexamethyldisilane reductant (1) generates the $\mathrm{Me}_{3} \mathrm{Si}^{-}$ anion (III), in agreement with previous findings, ${ }^{22}$ and this nucleophile is competent to deoxygenate $\mathrm{N}_{2} \mathrm{O}$ as discussed there above. Yet, its regeneration can proceed via two different pathways: either through the route described in Figure 1c, where the fluoride anion is playing the role of a precatalyst (Scheme 2, A), or through a route involving an actual catalytic activity of $\mathrm{F}^{-}$(Scheme 2, B). The latter implies the displacement of a fluoride anion from $\mathrm{Me}_{3} \mathrm{SiF}$, by the $\mathrm{Me}_{3} \mathrm{SiO}^{-}$silanolate (I). This reaction proceeds via an associative pathway, with the formation of a stable pentacoordinated intermediate $\mathbf{V}$ (Figure 2). The energy barrier involved in the regeneration

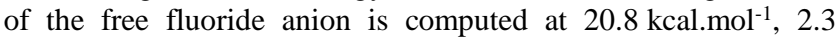
kcal.mol ${ }^{-1}$ greater than the energy span computed for the transformation catalyzed by the $\mathrm{Me}_{3} \mathrm{SiO}^{-}$silanolate. This small difference in energy suggests that $\mathrm{F}^{-}$is a precatalyst in the reduction of $\mathrm{N}_{2} \mathrm{O}$ by hexamethyldisilane.

In the reduction of $\mathrm{N}_{2} \mathrm{O}$ with hexamethyldisilane (1), the formation and regeneration of the silyl anion $\mathrm{Me}_{3} \mathrm{Si}^{-}$(III) controls the rate of the reaction. The latter attacks $\mathrm{N}_{2} \mathrm{O}$ preferentially at the central nitrogen and a subsequent barrier-less pseudo-Brook rearrangement releases $\mathrm{N}_{2}$. This mechanism also explains the trend observed with phenyl substituted disilanes $\mathbf{2}$ and $\mathbf{3}$ (Table 2). Indeed, with the more acidic disilanes $\mathbf{2}$ and $\mathbf{3}$, the rate of the reaction is no longer controlled by the regeneration of the silyl anion but by the addition of the silyl anion to $\mathrm{N}_{2} \mathrm{O}$, which involves low energy barriers of $15.0 \mathrm{kcal}^{\mathrm{mol}}{ }^{-1}$ and $15.2 \mathrm{kcal}^{\mathrm{mol}}{ }^{-1}$, respectively (see SI, Figures S12,S13). Thanks to this lower energy span, phenyl substituted disilanes $\mathbf{2}$ and $\mathbf{3}$ react faster than disilane $\mathbf{1}$ (Table 2).

In summary, we have developed the first transition metal-free catalytic deoxygenation of $\mathrm{N}_{2} \mathrm{O}$. The kinetic stability of this gas has been overcome by using disilanes as mild reducing agents, under ambient conditions $\left(1 \mathrm{bar}, 20^{\circ} \mathrm{C}\right)$, and in presence of catalytic amounts of fluoride anion or alkoxides. According to DFT calculations, the reaction proceeds through nucleophilic addition of a silyl anion to the central nitrogen of $\mathrm{N}_{2} \mathrm{O}$. The cleavage of the $\mathrm{N}-\mathrm{O}$ bond then results from a pseudo-Brook rearrangement to release $\mathrm{N}_{2}$ gas, triggered by the formation of a strong $\mathrm{Si}-\mathrm{O}$ bond.

\section{AUTHOR INFORMATION}

\section{Corresponding Author}

*lucile.anthore@cea.fr and thibault.cantat@cea.fr

Notes

The authors declare no competing financial interests.

\section{ASSOCIATED CONTENT}

\section{Supporting Information}


Detailed descriptions of experimental and computational methods are given in the Supporting Information, available free of charge on the ACS Publications website.

\section{ACKNOWLEDGMENT}

For financial support of this work, we acknowledge the CEA, CNRS, ANR (project RecyclingSiB) and the CHARMMMAT LABEX. We thank CINES for the allowance of computer time (Project No. c2019086494).

\section{REFERENCES}

(1) Lehnert, N.; Dong, H. T.; Harland; J. B., Hunt; A. P.; White, C. J. Reversing Nitrogen Fixation. Nat. Rev. Chem. 2018, 278-289.

(2) IPCC Report. Core Writing Team, R.K. Pachauri; L.A. Meyer (eds.), Geneva, Switzerland, 2014.

(3) Dameris, M. Depletion of the Ozone Layer in the 21st Century. Angew. Chem., Int. Ed. 2010, 49, 489-491.

(4) EPA, U. S. U.S. Greenhouse Gas Inventory Report 1990-2014

(5) (a) Nirisen, Ø.; Waller, D.; Brackenbury, D. M. The Development of a $\mathrm{N}_{2} \mathrm{O}$ Abatement Catalyst: from Laboratory Scale to Plant Testing. Top. Catal. 2018. doi:10.1007/s11244-018-1076-1. (b) Frutos, O. D.; Quijano, G.; Aizpuru, A.; Muñoz, R. A. State-of-the-art Review on Nitrous Oxide Control from Waste Treatment and Industrial Sources. Biotechnol. Adv. 2018, 36, 1025-1037.

(6) Johnston, H. S. Interpretation of the Data on the Thermal Decomposition of Nitrous Oxide. J. Chem. Phys. 1951, 19, 663-667.

(7) Tolman, W. B. Binding and Activation of $\mathrm{N}_{2} \mathrm{O}$ at Transition-Metal Centers: Recent Mechanistic Insights. Angew. Chem., Int. Ed. 2010, 49, $1018-1024$.

(8) (a) Leont'ev, A. V.; Fomicheva, O. A.; Proskurnina, M. V.; Zefirov, N. S. Modern Chemistry of Nitrous Oxide. Russ. Chem. Rev. 2001, 70, $91-$ 104. (b) Parmon, V. N.; Panov, G. I.; Uriarte, A.; Noskov, A. S. Nitrous Oxide in Oxidation Chemistry and Catalysis: Application and Production. Catal. Today 2005, 100, 115-131.

(9) Severin, K. Synthetic Chemistry with Nitrous Oxide. Chem. Soc. Rev. 2015, 44, 6375-6386.

(10) Handbook of Chemistry and Physics, 81st ed. D.R. Lide, 2000

(11) (a) Bottomley, F.; Lin, I. J. B.; Mukaida, M. Reactions of Dinitrogen Oxide (Nitrous Oxide) with Dicyclopentadienyltitanium Complexes Including a Reaction in which Carbon Monoxide is Oxidized. J. Am. Chem. Soc. 1980, 102, 5238-5242. (b) Kaplan, A. W.; Bergman, R. G. Nitrous Oxide Mediated Synthesis of Monomeric Hydroxoruthenium Complexes. Reactivity of (DMPE) $)_{2} \mathrm{Ru}(\mathrm{H})(\mathrm{OH})$ and the Synthesis of a Silica-Bound $\mathrm{Ru}-$ thenium Complex. Organometallics 1998, 17, 5072-5085. (c) Lee, J.-H.; Pink, M.; Tomaszewski, J.; Fan, H.; Caulton, K. G. Facile Hydrogenation of $\mathrm{N}_{2} \mathrm{O}$ by an Operationally Unsaturated Osmium Polyhydride. $J$. Am. Chem. Soc. 2007, 129, 8706-8707. (d) Tskhovrebov, A. G.; Solari, E.; Scopelliti, R.; Severin, K. Activation of Nitrous Oxide by Dinuclear Ruthenium Complexes. Organometallics 2012, 31, 7235-7240. (e) Doyle, L. E.; Piers, W. E.; Bi, D. W. Cationic PCP Iridaepoxide and Carbene Complexes for Facile Water Elimination and Activation Processes. Dalt. Trans. 2017, 46, 4346-4354. (f) Smith, J. D.; Chih, E.; Piers, W. E.; Spasyuk, D. M. Tuning Iridium(I) PCcarbeneP Frameworks for Facile Cooperative $\mathrm{N}_{2} \mathrm{O}$ Reduction. Polyhedron 2018, 155, 281-290. (g) Hartmann, N. J.; Wu, G.; Hayton, T. W. Synthesis and Reactivity of a Nickel(II) Thioperoxide Complex: Demonstration of Sulfide-Mediated $\mathrm{N}_{2} \mathrm{O}$ Reduction. Chem. Sci. 2018, 9, 6580-6588.

(12) Kiefer, G.; Jeanbourquin, L.; Severin, K. Oxidative Coupling Reactions of Grignard Reagents with Nitrous Oxide. Angew. Chem., Int. Ed. 2013, 52, 6302-6305.

(13) (a) Yamada, T.; Suzuki, K.; Hashimoto, K.; Ikeno, T. $\mathrm{N}_{2} \mathrm{O}$ Oxidation of Phosphines Catalyzed by Low-Valent Nickel Complexes. Chem. Lett. 1999, 28, 1043-1044. (b) Beloglazkina, E. K.; Majouga, A. G.; Moiseeva, A. A.; Zyk, N. V.; Zefirov, N. S. Oxidation of Triphenylphosphine and Norbornene by Nitrous Oxide in the Presence of $\mathrm{Co}^{\mathrm{II}} \mathrm{LCl}_{2}[\mathrm{~L}=3$-phenyl-5-(2-pyridylmethylidene)-2-thiohydantoin]: the First Example of $\mathrm{Co}^{\mathrm{II}}$ Catalyzed Alkene Oxidation by $\mathrm{N}_{2} \mathrm{O}$. Mendeleev Commun. 2009, 19, 69 71. (c) Gianetti, T. L.; Rodríguez-Lugo, R.E.; Harmer, J. R.; Trincado, M.; Vogt, M.; Santiso-Quinones, G.; Grützmacher, H. Zero-Valent Amino-Olefin Cobalt Complexes as Catalysts for Oxygen Atom Transfer Reactions from Nitrous Oxide. Angew. Chem., Int. Ed. 2016, 55, 15323-15328.
(14) Corona, T.; Company, A. Nitrous Oxide Activation by a Cobalt(II) Complex for Aldehyde Oxidation under Mild Conditions. Dalt. Trans. 2016, 45, 14530-14533.

(15) Gianetti, T. L.; Annen, S. P.; Santiso-Quinones, G.; Reiher, M.; Driess, M.; Grützmacher, H. Nitrous Oxide as a Hydrogen Acceptor for the Dehydrogenative Coupling of Alcohols. Angew. Chem., Int. Ed. 2016, 55, 1854-1858.

(16) Zeng, R.; Feller, M.; Diskin-Posner, Y.; Shimon, L. J. W.; Ben-David, Y.; Milstein, D.; CO Oxidation by $\mathrm{N}_{2} \mathrm{O}$ Homogeneously Catalyzed by Ruthenium Hydride Pincer Complexes Indicating a New Mechanism. $J$. Am. Chem. Soc. 2018, 140, 7061-7064. (b) Ricker, J. D.; Mohammadrezaei, V.; Crippen, T. J.; Zell, A. M.; Geary, L. M. Nitrous Oxide Promoted Pauson-Khand Cycloadditions. Organometallics 2018, 37, 4556-4559.

(17) Zeng, R.; Feller, M.; Ben-David, Y.; Milstein, D. Hydrogenation and Hydrosilylation of Nitrous Oxide Homogeneously Catalyzed by a Metal Complex. J. Am. Chem. Soc. 2017, 139, 5720-5723.

(18) (a) Dávalos, J. Z.; Baer, T. Thermochemistry and Dissociative Photoionization of $\mathrm{Si}\left(\mathrm{CH}_{3}\right)_{4}, \mathrm{BrSi}\left(\mathrm{CH}_{3}\right)_{3}, \mathrm{ISi}\left(\mathrm{CH}_{3}\right)_{3}$, and $\mathrm{Si}_{2}\left(\mathrm{CH}_{3}\right)_{6}$ Studied by Threshold Photoelectron-Photoion Coincidence Spectroscopy. J. Phys. Chem. A 2006, 110, 8572-8579. (b) Blanksby, S. J.; Ellison, G. B. Bond Dissociation Energies of Organic Molecules. Acc. Chem. Res. 2003, 36, 255-263.

(19) Hagen, A. P.; Jones, D. J. High-Pressure Reactions of Small Covalent Molecules. 9. Reaction of Methylsilanes with Covalent Oxides. Inorg. Chem. 1977, 16, 2265-2267.

(20) Fayolle, F.; Couderc, J.-P.; Duverneuil, P. Analysis and Modeling of SIPOS Deposition in a Hot Wall Tubular Reactor. Part II: Modeling of SIPOS Deposition. Chem. Vap. Depos. 1996, 2, 265-275.

(21) (a) Lescot, C.; Nielsen, D. U.; Makarov, I. S.; Lindhardt, A. T.; Daasbjerg, K.; Skrydstrup; T. Efficient Fluoride-Catalyzed Conversion of $\mathrm{CO}_{2}$ to CO at Room Temperature. J. Am. Chem. Soc. 2014, 136, 6142-6147.

(b) Lian, Z.; Nielsen, D. U.; Lindhardt, A. T.; Daasbjerg, K.; Skrydstrup T. Cooperative Redox Activation for Carbon Dioxide Conversion. Nat. Commun. 2016, 7, 13782. (c) Daasbjerg, K.; Jensen, F.; Skrydstrup, T.; Nielsen, D.; Lopez, S.; Flinker, M. Experimental and Theoretical Studies on the Reduction of $\mathrm{CO}_{2}$ to $\mathrm{CO}$ with Chloro(methyl)disilane Components from the Direct Process. Synlett 2017, 28, 2439-2444.

(22) Hiyama, T.; Obayashi, M.; Mori, I.; Nozaki, H. Generation of Metal-Free Silyl Anions from Disilanes and Fluoride Catalyst. Synthetic Reactions with Aldehydes and 1,3-Dienes. J. Org. Chem. 1983, 48, 912 914.

(23) This stands in agreement with the literature: Spialter, L.; Austin, J. D. The Cleavage of Silanes by Oxides of Nitrogen. J. Am. Chem. Soc. 1966, $88,1828$.

(24) (a) Still, W. C. Conjugate Addition of Trimethysilyllithium. A Preparation of 3-Silyl Ketones. J. Org. Chem. 1976, 41, 3063-3064. (b) Dervan, P. B.; Shippey, M. A. Trimethylsilylpotassium. Deoxygenation of Epoxides with Inversion of Stereochemistry. J. Am. Chem. Soc. 1976, 98, 1265-1267. (c) Sakurai, H.; Okada, A.; Kira, M.; Yonezawa, K. Trimethylsilylsodium. A New Preparation and Some Reactions Involving a Facile Electron Transfer from Trimethylsilyl Anion to Naphthalene. Tetrahedron Lett. 1971, 12, $1511-1514$

(25) (a) Yu, H.; Jia, G.; Lin, Z. Theoretical Studies on $O$-Insertion Reactions of Nitrous Oxide with Ruthenium Hydride Complexes. Organometallics 2008, 27, 3825-3833. (b) Xie, H.; Li, Y.; L. Huang, L.; Nong, F.; Ren, G.; Fan, T.; Lei, Q.;Fang, W. Dehydrogenation of Benzyl Alcohol with $\mathrm{N}_{2} \mathrm{O}$ as the Hydrogen Acceptor Catalyzed by the Rhodium(I) Carbene Complex: Insights from Quantum Chemistry Calculations. Dalt. Trans. 2016, 45, 16485-16491. (c) Yao, L.; Li, Y.; Huang, L.; Guo, K.; Ren, G.; Wu, Z.; Lei, Q.; Fang, W.; Xie, H. A DFT Study on the Mechanisms of Hydrogenation and Hydrosilylation of Nitrous Oxide Catalyzed by a Ruthenium PNP Pincer Complex. Comput. Theor. Chem. 2018, 1128, 48-55.

(26) (a) Tskhovrebov, A. G.; Solari, E.; Wodrich, M. D.; Scopelliti, R.; Severin, K. Covalent Capture of Nitrous Oxide by $N$-heterocyclic Carbenes. Angew. Chem., Int. Ed. 2012, 51, 232-234. (b) Tskhovrebov, A. G.; Vuichoud, B.; Solari, E.; Scopelliti, R.; Severin, K. Adducts of Nitrous Oxide and $N$-Heterocyclic Carbenes: Syntheses, Structures, and Reactivity. $J$. Am. Chem. Soc. 2013, 135, 9486-9492. (c) Eymann, L. Y. M.; Scopelliti, R.; Fadaei, F; T.; Cecot, G.; Solari, E.; Severin, K. Fixation of Nitrous Oxide by Mesoionic and Carbanionic $\mathrm{N}$-Heterocyclic Carbenes. Chem. Commun. 2017, 53, 4331-4334.

(27) (a) Otten, E.; Neu, R. C.; Stephan, D. W. Complexation of Nitrous Oxide by Frustrated Lewis Pairs. J. Am. Chem. Soc. 2009, 131, 9918-9919. (b) Neu, R. C.; Otten, E.; Lough, A.; Stephan, D. W. The Synthesis and 
Exchange Chemistry of Frustrated Lewis Pair-Nitrous Oxide Complexes. Chem. Sci. 2011, 2, 170-176.

(28) Mayr, H.; Breugst, M.; Ofial, A. R. Farewell to the HSAB Treatment of Ambident Reactivity. Angew. Chem., Int. Ed. 2011, 50, 6470-6505.

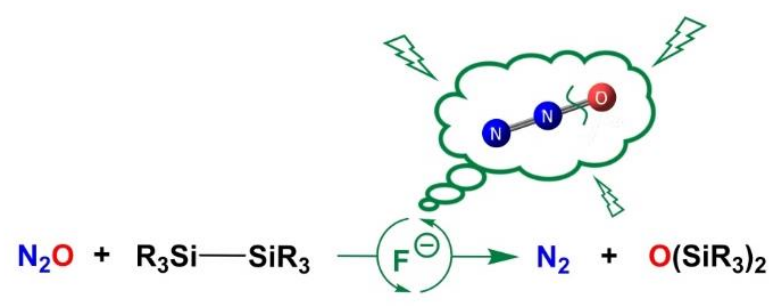

\section{Table of Contents artwork}

(29) Liu, Y.; Eymann, L. Y. M.; Solari, E.; Fadaei Tirani, F.; Scopelliti, R.; Severin, K.Trimethylsilyl-Induced N-O Bond Cleavage in Nitrous Oxide-Derived Aminodiazotates. Inorg. Chem. 2018, 57, 11859-11863. 